\title{
Working women and per capita household consumption expenditures; an untouched reality*
}

\author{
Wen Jun ${ }^{1}$, Junaid Waheed ${ }^{2}$, Hadi Hussain ${ }^{3}$, Ihsan Jamil ${ }^{4}$, \\ Denisa Borbášová ${ }^{5}$, Muhammad Khalid Anser ${ }^{6}$
}

\begin{abstract}
Working women have more compulsive buying tendencies which can lead to a significant increase in their household consumption expenditures. This study investigates the effects of changes in the number of working women on household per capita consumption. We test the hypothesis that changes in the number of working women have a discernible impact on household final per capita consumption expenditures, due to their differing consumption propensities, by doing an empirical analysis based on panel data set of 36 OECD economies within the period 2000-2016. The results indicate that changes in the number of working women increase the household per capita consumption expenditures. The result
\end{abstract}

* Received: 15-10-2019; accepted: 20-04-2020

1 Professor of Economics, Assistant Vice Dean, Xain Jiaotong University, School of Economics and Finance, 74 Yanta Road, Xian, 710000, China. Scientific affiliation: applied economics, corporate finance, industrial organization and enterprise innovation. Phone: +86 02982656840.E-mail:wjun1978@163.com.

2 Ph.D. Scholar, Xain Jiaotong University, School of Economics and Finance, 74 Yanta Road, Xian, 710000, China. Scientific affiliation: applied economics, macroeconomics, consumer behavior, and innovation. Phone: +86 18149056075.E-mail: junaidwaheed@stu.xjtu.edu.cn. (corresponding author).

3 Ph.D. Scholar, Xain Jiaotong University, School of Economics and Finance, 74 Yanta Road, Xian, 710000, China. Scientific affiliation: applied economics, industrial organization, corporate finance, corporate governance and enterprise innovation. E-mail: hussainhadi@stu.xjtu.edu.cn.

4 Ph.D. Scholar, Xain Jiaotong University, School of Economics and Finance, 74 Yanta Road, Xian, 710000, China. Scientific affiliation: macroeconomics, agriculture economics, innovation and public policy.E-mail: ihsanjamil@stu.xjtu.edu.cn.

5 Master in Management, Student, Xain Jiaotong University, School of Management, 28 Xianning Road, Xian, 710000, China. Scientific affiliation: managerial economics, consumer behavioral analysis and consumer studies.E-mail: borbasova.d@gmail.com.

${ }^{6}$ Ph.D. Researcher, School of Management, Xi'an University of Architecture and Technology, Beilin, 710000, China. Scientific affiliation: applied economics, industrial organization, corporate finance and corporate governance.E-mail: khalidsnnu@gmail.com. 
also implies that age plays a significant role in working women consumption decision making and may lead to significant differences in aggregate consumption expenditure. These findings suggest the importance of understanding changes in the number of working women in planning for aggregate consumption mobilization and in the formulation of aggregate growth policies.

Key words: working women buying behavior, household per capita consumption expenditures, GDP growth, empirical study, OECD countries

JEL classification: D12, D91, J16

\section{Introduction}

Consumption is considered to be an essential element for the most part of macroeconomic models since it takes from about $50 \%$ to $70 \%$ of gross domestic product in most economies. ${ }^{7}$ It is important to explore all the critical factors which influence consumption expenditures. ${ }^{8}$ Compulsive behavior of women with respect to buying decision is of significant importance and need to be examined thoroughly/ in detail. Women's spending behavior is quite different from men's be. Their marginal propensity to consume is relatively higher making them strong consumers (Kornrich and Roberts, 2017). Specifically working women, due to their high purchasing power, are considered as more imprudent to consumption decisions ${ }^{9}$. Thus we investigated the phenomena in respect of working women. To learn about household final per capita consumption expenditures through working women spending behavior is crucial for the macroeconomic perspective of the economy.

Over the last half-century, the percentage of working women has increased enormously almost everywhere in the world ${ }^{10}$. The consequences for family performance and lifestyle patterns once the woman's main working hours are removed from home are vast in magnitude (Anderson and Eswaran 2009; Lancaster, Maitra and Ray, 2008). Despite the implication of this social trend, inadequate consideration appears to have been paid to investigating its implications for encouragement policies. Relatively little interest seems, such as, to have been publicized in assessing whether working women families have exact needs and interests which provide opportunities for mounting new products and services,

\footnotetext{
7 For example, in 2017, USA personal consumption expenditures were $\$ 12.6$ trillion, contributing 70 percent of total United States real GDP.

8 In this research for examining gross domestic product as a means to comprehend what is holding back country's economic situation, we will examine consumption expenditures through an important channel of working women expenditure behavior.

9 Detailed explanation is given on the next pages.

${ }^{10}$ According to global professional services firm estimates, worldwide aggregate incomes of women are calculated to reach an astounding \$18 trillion by 2018 . Women impel $70-80 \%$ of the entire consumer buying, through a amalgamation of their own buying power and influence on others. (Forbes estimates)
} 
Wen Jun et al. •Working women and per capita household consumption expenditures...

or for emphasizing definite benefits and appeals. When we question the relation between number of working women on per capita consumption expenditure, the first answer directly comes up is income effect, which explains the changes in their consumption pattern. However, except for the income effect there are many other factors explaining the different consumption propensities of working women.

Despite the fact that working women's compulsive buying behavior ${ }^{11}$ makes them spend relatively more than men $^{12}$ and the income effect, there are other reasons making working women particularly spend larger proportions of their income. The following reasons show that this neglect of the working women consumption expenditure pattern is unjustifiable. Firstly, the time constraints on the routine of household tasks such as cooking, grocery, cleaning, and in particular on the time when these household tasks are performed in working women's families, propose that different strategies are probably to be developed to deal with these problems. One supposition is that working women will show more interest in time-saving products and services such as take-out meals, instant dusting sprays, laundry, and cleaning service. Secondly, working women's lifestyle is comparatively different to non-working ones. They spend more on their personal grooming, clothing and other things. Thirdly, dissimilarities in attitudes among working and non-working women in the direction of female roles are likely to influence their consumption behavior. The double roles of a woman in her employment and in the home entail that the degree of involvement in different "homemaker" responsibilities such as "Chief Cook", "Housekeeper", "Mother", will differ from a non-working woman for whom such functions are the focal point of her continuation (Shotick, 2015). This does not essentially mean rejection of homemaker functions by working women, but rather that the search for other chances for self-fulfillment in activities outside the home (Keng and Lin, 2005). Therefore, the time and effort dedicated to homemaker roles, as well as concepts of opposite behavior in these functions, may differ from those of the non-working women (Killewald 2011). Based on all these phenomena we build the first hypothesis that the number of working women has significant effect on consumption expenditures.

With the raise in number of working women in past decades, economic activity amplified extensively (Albanesi, 2017). Their participation leads higher growth in different economic indicators. Working women spending behavior is one of the aspects which is helping economic doings and improving the living standards. Women participate in 70-80 percent of the overall consumer spending ${ }^{13}$. Therefore,

\footnotetext{
${ }^{11}$ Compulsive buying behavior is the psychiatric nomenclature which is characterized by excessive or poorly controlled urges or behaviors related to buying and spending.

${ }^{12}$ For example, in the research it is estimated that compulsive buying behavior affected between 2 to 16 percent of the United States population and that 90 percent of sufferers were women.

${ }^{13}$ In Bridget Brennan's article published in Forbes news on May 20, 2019, she quoted women as the world's most powerful consumers.
} 
supposedly higher women spending leading more household expenditures ultimately affect to the aggregate consumption expenditures. To understand the concept on extensive level, a macro level analysis had better be done as to investigate the connection between number of working and aggregate consumption expenditures. Thus the second hypothesis is that the a positive change in numbers of working women increases per capita household consumption expenditures.

Likewise, if we imply the above reasons for different age groups of working women, there are significant differences between the buying behaviors of different age groups (Addessi, 2018). Generally, young women have relatively more compulsive buying behavior than middle-aged and elderly women. However, middle-aged working women spend more on family expenditures. It is empirically proven that working wives increase their expenditures on family necessities such as children education, clothing, non-durable etc. (DeWeese and Norton, 1991). Limited attention has been paid to investigating the impact of the women's employment status on buying behavior and on their consumption expenditures. A few comparisons of purchase behavior in working and non-working women's families have been made.. For instance, it has been found that working women tend to be more efficient in organizing household tasks; they make fewer shopping trips and are more likely to be accompanied by their husbands than non-working women (Lee, Lee and Chang, 2014). On the other hand, there appears to be little support to indicate that working women are more interested in convenience products than nonworking women (Bhupal and Sam, 2014). Such studies are not based on complete information and barely scratch the surface of the working women phenomenon. Thus the third hypothesis is that the age of working women does matter on their spending decision and eventually to overall consumption expenditures.

The main purpose of the study is to investigate the effect of changes in the number of working women on household final per capita consumption expenditure ${ }^{14}$. The key research purpose is to find whether changes in working women appear to have a substantially significant effect on household consumption expenditure, which likely to give an adequate basis for measuring household final per capita consumption expenditure. In addition, to investigate whether there are significant attitudinal differences within different age groups of working women which show the way to different spending behavior patterns, and suggest that a finer level of study based on sub-segments within each group is possible to be more appropriate for decisionmaking purposes.

The rest of this study is organized as follows. Section 2 is the literature review on studies and theories that are related to Consumption expenditures and working

\footnotetext{
${ }^{14}$ Whereas while estimating through income approach, aggregate consumption is the first part of gross domestic Product. Hence we ultimately are looking for working women participation in economic growth through consumption channel.
} 
Wen Jun et al. •Working women and per capita household consumption expenditures...

women consumption behavior. Section 3 presents a brief introduction of the variables and data employed here. Section 4 establishment of the econometric model and section 5 provides the basic empirical results. Section 6 summarizes the Conclusion. Discussion and policy implications are presented in the final section.

\section{Literature review}

The most part of the economic literature on consumer spending views all households as compound decision-making entities with common preferences and pooled incomes. Such as, studies done by Apps and Rees (1997), Chen and Woolley (2001), Browning (2010) and d'Aspremont et al. (2019) view in favor of broadening the collective model of household spending behavior. Whereas, also number of studies rejecting this 'income-pooling' predicting the household utility framework is available in the literature ${ }^{15}$ (see, e.g. Schultz, 1990; Bourguignon et al., 1993; Hoddinott and Haddad, 1995; Lee, 2007; Browning et al., 2013; Watson et al., 2013; Beblo\& Beninger, 2016).

Women show compulsiveness in shopping as they look for corroboration of a sense of worth through shopping and spending (Dittmar, Beattie \& Friese, 2004). The working women have attained high on irrational buying scale as their pressure to match the manifestation requirement in terms of buying and spending are more as they are exposed to relatively wider social pressure. The other cause could be that the working women are more strained due to anxiety and high work pressure. They do shopping to do away with stress. Shopping plays a psychosomatic function in their lives (Dittmar, 2000; Dittmar, 2001). It will be not erroneous to say that shopping is a leisure activity for them. Taking this aspect into consideration, it can be concluded that it is not only the working women's economic dominion that makes them open to irrational buying tendencies but also socialization. Credit card availability is also supposed to be one of the causes for overspending (Joji \& Raveendran, 2008; Joireman, Kees \& Sprott, 2010) working women, being the earning entity can get the facility of credit cards that provide them access to more purchasing power. The current growth in retail malls and other amenities of online buying work as a fuel in the fire for the rising tendency to buy. Shopping which conventionally was considered as a trail of moral and mystical decay (Hirschman, 1992) is now regarded as a symbol of social vanity.

\footnotetext{
${ }^{15}$ However, there is not any single study analyzing proposed questions in this study empirically. Previous studies basically mostly presenting related theoretical concepts and those with empirical analysis are basically examining some other similar ideas using micro-level survey data for particular region. This study examines widely the whole concept using macro-level data with accurate econometric techniques and concluding general results.
} 
Phipps and Burton (1998) concluded that Male and female earnings do not always exert the same influences on household consumption expenditures. They found that husbands and wives are each more possible to use their own earnings for the things of private consumption (taking clothing, for example, is a private household consumption category) and that expenditures on household public goods reflect gendered spheres of responsibility (assuming children education expenses, for example, is a public household consumption category). Manchanda (2010) found that there is a major dissimilarity in the compulsive buying tendencies of working and non-working women. The study indicated that nonworking women are less compulsive buyers than working women while the level of socialization might be one of the factors for the equivalent. In another study (Manchanda 2015) the author talk about the question of whether the young generation is actually moving towards covetousness and compulsive buying inclinations?

Svaleryd (2009) did an empirical analysis on women representation and public spending and found the gender as a significant determinant of public spending. According to the results women's representation affects spending on childcare, education and elderly care. Schmeer (2005) investigated how married women use their access to and manage over economic resources to raise household spending on food. The study, using data from Cebu, Philippines, found that the household with more women earning spends more on food. The study also indicated that the women's control over their income is mainly important for expanding food expenses in the poorest households. While in richer households, women who make little of their own earnings also use husband income transfers to expend food expenditures.

Foster and Mammen (1992) indicated that wife's employment status was significantly explained expenditure on food away from home, on child care and on total services only. Conversely, to what may be expected, only families of parttime working wives increased expenses on food away from home comparative to families of full-time homemakers. Hopkins, Levin, and Haddada (1994) used a gender-disaggregated cyclic consumption model to explore whether the flow of income or the gender of an income earner or both, manipulates household spending patterns at a given level of household income? The study found that for the total household expenditures, the gender of the income earner matters, given that the annual income is not pooled and together the flow of overall income and the flow of gender-specific income are significant determinants of household consumption expenditures.

Household production variables have a significant impact on service expenses (Soberon and Dardis, 1991). The study examined the factors influencing household spending for services in the United States and found a significant difference between the families with full-time and part-time working wives in expenses on child care, on food away from home, and on total services. Fisher (2010) empirically estimated 
that women are less possible to save in the short term if they are in poor health, whereas poor health does not significantly change the short term saving of men. Ganita and Abdoul (2014) estimated the effect of female income on children expenditures after an increase in income through the National Rural Employment Guarantee Scheme (NREGS) program. The study indicated that female income has a significant increase in the expenditure share of children's clothing and footwear consumption, and this positive urge happens on account of a major increase in the expense share for boys. Male income, from the program, on the other hand, has no impact on children expenditure for the considered categories. Zamora (2011) checked the Causal effect of female labor contribution on household consumption expenditures and found that female labor contribution causes an increase in the consumption expenditure of several commodities based on visible household characteristics. Female labor contribution also causes changes in consumption expenditures that are unobservable for us but are pragmatic and considered by the household at the time when it decides whether the women participate.

The above-mentioned literature has investigated a number of direct and indirect effects of the working women spending behavior on household consumption expenditures and has found a lot of positive impacts in this regard. This paper adds to the aforementioned literature by exploring another effect of working women buying behavior on per capita consumption expenditure. Specifically, we analyze different age group buying attitude and their effects on expenditure. This study, as a result, fills some gaps in our understanding of the relation between working women and consumption expenditures.

\section{Methodology}

On the basis of previous literature and following the life cycle/ permanent income hypothesis, we employ the permanent consumption model. The model says that consumption is a function of Permanent Income ${ }^{16}$ is

$$
C=f(I, Z)
$$

Here ' $C$ ' represents real per capita Aggregate consumption, ' $I$ ' is the real per capita Income and ' $Z$ ' is the vector of other factors affecting Aggregate consumption. However, as in this research we are interested to find how women work participation affect aggregate consumption, our interest variable that is working women is a binding factor in consumption decision. Thus to take in factor into account, we used the following regression

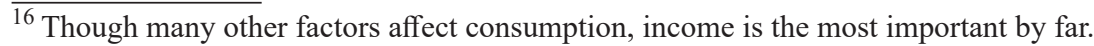




$$
C=a_{0}+\beta_{i} I+\beta_{w w} W W+\beta_{z} Z+\mu
$$

where ' $W W$ ' represents the total number of working women. To measure the effect of change in total number of working women on consumption, we formulate a model using difference of the main variables as if we include them in level form, the results will only show their relationship in level. So, it is necessary to include difference of each real variable (real per capita consumption, real per capita income and total number of working women). We will include log difference of the variables to allow the direct estimation of consumption elasticities. Moreover, we also include the other determinents of aggregate consumption ${ }^{17}$. Therefore, the full regression specification will be:

$$
\begin{aligned}
& \Delta \ln C_{i t}=a_{0}+\beta_{i} \Delta \ln I_{i t}+\beta_{w w} \Delta \ln W W_{i t}+\beta_{f r} \Delta F R_{i t}+\beta_{c p i} \Delta C P I_{i t}+ \\
& +\beta_{p p p} \Delta P P P_{i t}+\mu
\end{aligned}
$$

Now further we can also include alienated categories of young, middle and old working women in equation.

$$
\begin{aligned}
& \Delta \ln C_{i t}=a_{0}+\beta_{i} \Delta \ln I_{i t}+\beta_{w w} \Delta \ln W W_{i t}+\beta_{f r} \Delta F R_{i t}+\beta_{c p i} \Delta C P I_{i t}+ \\
& +\beta_{p p p} \Delta P P P_{i t}+\beta_{y w w} \Delta \ln Y W W_{i t}+\beta_{m w w} \Delta \ln M W W_{i t}+\beta_{o w w} \Delta \ln O W W_{i t}+\mu
\end{aligned}
$$

where $C_{i t}$ is the real annual aggregate consumption of country $i$ at time $t ; I_{i t}$ is the real annual income of country $i$ at time $t$; $W W_{i t}$ is the total number of working women of country $i$ at time $t ; F R_{i t}$ is the fertility rate of country $i$ at time $t ; C P I_{i t}$ is the annual consumer price index of country $i$ at time $t ; P P P_{i t}$ is the purchasing power parity from country $i$ at time $t$; $Y W W_{i t}$ is the total number of young working women of country $i$ at time $t$; $M W W_{i t}$ is the total number of middle working women of country $i$ at time $t$; $O W W_{i t}$ is the total number of old working women of country $i$ at time. Now the impact of a one unit change in number of working women is calculated as:

$$
\mathrm{dC} \frac{1}{C}=\mathrm{dWW}\left[\beta_{w w} \frac{1}{\mathrm{WW}}\right]
$$

By re-arranging the equation

$$
\Rightarrow \frac{\mathrm{dC}}{d W W}=\frac{\overline{\mathrm{C}}}{\overline{W W}}\left[\beta_{w w}\right]
$$

\footnotetext{
${ }^{17}$ On basis of literature, we include only those variables which may cause change in per capita consumption. These include income, population (measuring through fertility rate), inflation (measuring by consumer price index) and purchasing power parity. Although there is large number of literature considered wealth as a necessary determinant of consumption. Due to unavailability of data we skip this variable in our model.
} 
Wen Jun et al. - Working women and per capita household consumption expenditures...

where bar on a variable indicates its sample mean. As the change in consumption due to change in number of working women is referred working women effect so this analogous derivative will be the working women effect (WWE) is $\frac{\mathrm{dC}}{d W W}$, therefore working women effect can be estimated by:

$$
\mathrm{WWE}=\frac{\overline{\mathrm{C}}}{\overline{W W}}\left[\beta_{w w}\right]
$$

Now to estimate the consumption elasticity of working women above equation becomes:

$$
\varepsilon_{w w}=\frac{d C}{d w W} \div \frac{\overline{W W}}{\bar{C}}=\beta_{w w}
$$

So by estimating the value of $\beta_{w w}$ in above equation (4), we will calculate the consumption elasticity of working women. Similarly, the coefficient of young working women, middle working women and old working women variable represent their consumption elasticities.

$$
\begin{aligned}
& \varepsilon_{y w w}=\frac{\mathrm{dC}}{d Y W W} \div \frac{\overline{Y W W}}{\bar{c}}=\beta_{y w w} \\
& \varepsilon_{m w w}=\frac{\mathrm{dC}}{d M W W} \div \frac{\overline{M W W}}{\bar{c}}=\beta_{m w w} \\
& \varepsilon_{o w w}=\frac{\mathrm{dC}}{d M W W} \div \frac{\overline{M W W}}{\bar{c}}=\beta_{o w w}
\end{aligned}
$$

Cross-sectional dependence is an important issue in panel data econometrics. It will be wide of the mark to assume in order to errors are cross-sectionally not dependent and slopes are homogeneous. Due to the appearance of micro panel data in which both the cross-section $(\mathrm{N})$ and the time series $(\mathrm{T})$ dimensions are large, it is necessary to test for cross-sectional dependence. Cross-correlated errors may be grounded by numerous issues, for instance omitted frequent effects, connections contained by socioeconomic systems, and spatial possessions (Chudik and Pesaran 2013).

Ignoring cross-sectional dependence can cause inadvertent outcomes. Firstly, conventional unit root tests have considerable size deformations if the errors are cross-sectionally dependent (O'Connell 1998). Secondly, overlooking crosssectional dependence by using fixed or random effect methodologies is likely to create incompatible and biased predictors (Sarafidis and Robertson 2009). The cross-sectional dependence of errors is tested by using the $\mathrm{CD}$ test given by Pesaran $(2004)^{18}$. The CD test is used at the time when cross-sectional aspect is larger

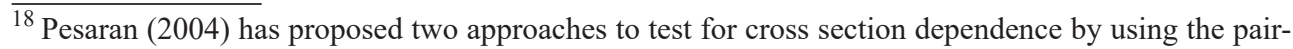
wise correlation coefficients of residuals in the regression equations. In Monte Carlo experiments it
} 
than the time characteristic in the panel $(\mathrm{N}>\mathrm{T})$. This check is robust to structural breaks, as well as non-normality of the errors. But, it might be inconsistent if the cross-sectional dimension is lesser than the time characteristic in the panel $(\mathrm{N}<$ T). The bias-adjusted LM test given by Pesaran and Yamagata (2008) explains the inconsistency problem. In this revision, though panel data is used with more number of cross-sections than years $(\mathrm{T}>\mathrm{N})$, we formulate use of both tests to make sure whether cross-sectional dependence presents in our data. The CD test statistic is intended as follows:

$$
C D=\sqrt{\frac{2 T}{N(N-1)}} F\left(\sum_{i=1}^{N-1} \sum_{j=i+1}^{N} \rho_{i j}\right) \sim N(0,1), i, j=1,2,3, \ldots, N
$$

the bias-adjusted description of the $\mathrm{CD}$ test is

$$
L M=\sqrt{\frac{2 T}{N(N-1)} F\left(\sum_{i=1}^{N-1} \sum_{j=i+1}^{N} \rho_{i j}\right) \frac{(T-k) \rho_{i j}^{2}-E(T-k) \rho_{i j}^{2}}{\operatorname{Var}(T-k) \rho_{i j}^{2}}}
$$

in which $\hat{r}_{i j}$ is the model estimation of the pair wise correlation of residuals taken by ordinary least square (Hernández-Salmarón and Romero-Ávila 2015).

As the results on above test indicated cross-sectional dependence in the series, subsequently we employed the CIPS panel unit root test (Pesaran 2007) ${ }^{19}$, which is robust toward cross-sectional dependence. The CIPS panel unit root test uses the subsequent augmented Dickey-Fuller regression to compute the cross-sectionally augmented ADF statistic (CADF).

$$
\Delta y_{i, t}=a_{i}+b_{i} y_{i, t-1}+c_{i} \bar{y}_{t-1}+d_{i} \Delta \bar{y}_{t}+\varepsilon_{i t}
$$

where $\bar{y}_{t-1}=\frac{1}{N} \sum_{i=1}^{N} y_{i}, \Delta y_{t}=\frac{1}{N} \sum_{i=1}^{N} \Delta y_{i, t}$ and $\varepsilon_{i t}$ is the error term. Then, using the CADF statistic computed above, the CIPS statistic is resulting as shown in Equation

$$
\text { CIPS }=\frac{1}{N} \sum_{i=1}^{N} C A D F_{i}
$$

comes out that the $\mathrm{CD}$ test has the right size for any combinations of $\mathrm{N}$ and $\mathrm{T}$ while the LM test goes with $\mathrm{T}$ large relative to $\mathrm{N}$.

${ }^{19}$ Pesaran (2007) proposed an alternative unit root test where the ordinary augmented Dickey-Fuller regressions are improved with the cross-section averages of the lagged levels and first-differences of individual series. 
Wen Jun et al. - Working women and per capita household consumption expenditures...

Furthermore, the Dumitrescu-Hurlin test is used to check the existence of panel causality. The test entails the following model:

$$
y_{i, t}=\alpha_{i}+\sum_{i=k}^{K} \beta_{i} y_{i, t-k}+\sum_{i=k}^{K} \gamma_{i} x_{i, t-k}+\varepsilon_{i, t}
$$

in which $y_{i, t}$ and $x_{i, t}$ are the interest variables, $k$ is the lag order, $\alpha_{i}$ is the constant, and $\varepsilon_{i, t}$ is the error term. The Dumitrescu-Hurlin panel causality test supposes the nonexistence of causality for all the individual variable in the panel and describes the null hypothesis as follows:

$$
\mathrm{H}_{0}=\gamma_{i 1}=\gamma_{i 2}=\ldots=\gamma_{i k}=0, \mathrm{H}_{\mathrm{i}}=1,2, \ldots, \mathrm{N}
$$

The other hypothesis states that there is as a minimum one Granger causal relationship in the panel:

$$
\begin{aligned}
& \mathrm{H}_{0}=\gamma_{i 1}=\gamma_{i 2}=\ldots=\gamma_{i k}=0, \mathrm{H}_{\mathrm{i}}=1,2, \ldots, \mathrm{N}_{1} \\
& \gamma_{i 1} \neq 0 \text { or } \gamma_{i 2} \neq 0 \text { or } \gamma_{i k}=0, \mathrm{H}_{\mathrm{i}}=\mathrm{N}_{1}+1,2, \ldots, \mathrm{N}
\end{aligned}
$$

in which $\mathrm{N}_{1} \in[0, \mathrm{~N}-1]$. The Dumitrescu-Hurlin test creates the Wald statistic (W) to test the null hypothesis and then calculates the $\mathrm{W}$ statistic by taking the average of $\mathrm{N}$ individual Wald statistics.

$$
\bar{W}=\frac{1}{N} \sum_{1}^{N} W_{i}
$$

And assuming that the Wald statistics are independently and identically distributed by crosswise individuals, the consistent $\mathrm{Z}$ and $\widetilde{Z}$ Wald statistics can be computed as follows:

$$
\begin{aligned}
& \bar{Z}=\sqrt{\frac{N}{2 K}}(\bar{W}-K) \\
& \tilde{Z}=\sqrt{\frac{N}{2 K}\left(\frac{T-3 K-5}{T-2 K-3}\right)\left(\frac{T-3 K-3}{T-3 K-1}\right)}(\bar{W}-K)
\end{aligned}
$$

in which $\mathrm{T}$ is the number of times, $\mathrm{N}$ is the number of cross sections, and $\mathrm{K}$ is the number of lags. If the computed $\bar{Z}$ and $\widetilde{Z}$ Wald statistics are larger than the critical values, then the null hypothesis is rejected, representing causality between series.

In next section the above equations are estimated using different econometric techniques. And results are shown at the end. 


\section{Empirical data and analysis}

The selected variables for the study are household actual per capita final consumption expenditures (as consumption), total number of employed women (as a proxy working women), net actual per capita national disposable income (as income), consumer price index (as an alternative for inflation), per capita gross domestic product, purchasing power parity, men unemployment rate, and fertility rate. Below, we give an explanation of our measures for variable assortment and also source/ explanation/structure of the data by evaluating our construction and that of analogous studies.

\subsection{Data and variables}

We choose countries on basis of some criteria, be going to pick up the variety of the data all the way through the size, arrangement, and regional dissimilarity of the countries as in the existing similar literature (i.e., see Slacalek, 2009). On basis of data availability and modeling constraints, it is decided to use the annual panel data of 36 advanced countries including moderately small advanced economies, such as New Zealand, Finland, Czech Republic, New Zealand, and Sweden as well as large countries, such as Italy, Australia, France, the UK, Japan, Canada, and the US, from the year 2000 to $2016^{20}$. Also, the research focuses on the number of working women which in a way presenting female labor force participation. That is relatively higher in OECD's countries than the other developing and non-developed nations. Therefore, it was evenhanded to go with the given sample for this research. The precise descriptions of all variables are given below.

\subsubsection{Dependent variable}

Household final per capita consumption expenditure

Studied like Mccarthy and Kilic (2015) and Hossain et al (2015) used household per capita final consumption, collect by world bank indicators, as consumption expenditures. Household per capita final consumption expenditure (per capita private consumption) is calculated by using private consumption in constant 2010 prices and World Bank population approximates.

Household per capita final consumption spending is the market value of all goods and services, together with durable products (such as home appliances, cars, and home computers), purchased by family units. It excludes purchases of private housing but includes imputed rent for the owner has taken dwellings.

$\overline{{ }^{20} \text { All the data for } 36}$ OECD countries from the year 2000 to 2016 is obtained from OECD Statistics and World Bank Indicators. 
Wen Jun et al. •Working women and per capita household consumption expenditures...

It also includes payments and fees to governments to attain permits and licenses. Moreover, household consumption expenditure includes the spending of nonprofit institutions helping households, even while reported independently by the country. Data are at constant 2010 U.S. dollars.

\subsubsection{Independent variable}

Number of working women

The labor force data on employment by sex and by standard age groups (15-34, $35-54,55+$, total) is used as a number of working women. ${ }^{21}$ The data is collected for full-time employed women. While the women in part-time employment, involuntary part-time employment or economic short-time works are not classified as fully employed workers. On average the persons whose usual working hours for all jobs are totally less than 35 to 40 hours per week are considered as part-time workers. Whereas, unpaid family workers who are working less than 15 hours per week, are not classified as employed. Population figures reported in labor force statistics (LFS) employment data by sex are Census-based, while the data tables are taken from labor force surveys.

Based on previous literature (i.e. Dreger and Reimers 2012; Desta 2014 and Biyun 2014) we used other explanatory variables including Per capita income, Fertility rate, Consumer price index, Male unemployment rate and Purchasing power parity in regression analysis. The details are as follows.

\subsubsection{Other explanatory variables}

In the research we use other explanatory variables as follows: per capita income, fertility rate, consumer price index, men unemployment rate, and purchasing power parity. More detailed explanation is presented below:

\section{Per capita income}

Net national income is calculated by GNI minus consumption of fixed capital. It also excludes natural resources depletion. Datta and Meerman (1980) using U.S. data in comparison to Malaysian distribution found per capita income as a better measure of welfare analysis than household income. Thus, we used per capita income data estimated at constant 2010 U.S. dollars and World Bank population approximates.

\footnotetext{
${ }^{21}$ Total employed women are considered here as total number of working women. Including total number of employed women, data is also separately collected for three categories based on age groups such as young, middle, and old those are divided as in ages 15-34, 35-54, and 55+ respectively.
} 


\section{Fertility rate}

Asumadu-Sarkodie, Owusu, and Zhang (2016) found bidirectional causality between household per capita final consumption expenditure and fertility rate. Total fertility rate stands for the number of children that born to a woman if she were to live to the end of her childbearing years and put up with children in respect to agespecific fertility rates of the specified year. Data is taken from OECD statistics.

\section{Consumer price index (Inflation)}

Inflation is measured by the consumer price index, which gives an idea about the annual percentage change in the charge of acquiring a container of goods and services (that perhaps predetermined or distorted at specified periods) to the standard consumer.

Inoue, Kilian and Kiraz (2009) explain that the reaction to inflation news cause an increase in households' education level, dependable with the continuation of constraints on household's capability to route this information. Thus leads a change in consumer decision making. Whereas, when the expected inflation rate could not be observed, the real consumption would be only affected by the judgment error of unobservable price increase (Han and Hung 2006).

\section{Male unemployment rate}

Unemployment considerably affects short term consumer spending decisions. Koç (2015) explains how these short term changes make a considerable impact on aggregate consumption expenditures. Unemployment refers to the share of the labor force that is devoid of work but available for and looking for employment. Definitions of labor force and unemployment differ by country. The data on unemployment of OECD countries is collected from Labor Force Statistics (LFS).

\section{Purchasing power parity}

According to Asian Development Bank report (2015), the PPPs are collected by major economic aggregates which measure the real per capita actual final consumption expenditure. PPPs are the rates of currency exchange that make equal the purchasing power of different currencies by eliminating the disparities in price levels between countries. In their simplest form, PPPs are basically price relatives that show the proportion of the prices in national currencies of the identical good or service in different countries. PPPs are also calculated for manufactured goods groups and for each of the different levels of aggregation up to and counting GDP.

Once dividing the household aggregate consumption and income data by the interpolated total population data, we obtain the data for consumption and income 
Wen Jun et al. •Working women and per capita household consumption expenditures...

per capita variables, respectively. We deflated all nominal data apart from interest rates by the CPI and take the natural logarithm of all variables to build a log-log model, which let us to compute elasticities. Table 1 gives you an idea about the descriptive statistics.

Table 1: Summary statistics

\begin{tabular}{|l|c|c|c|r|r|}
\hline \multirow{2}{*}{\multicolumn{1}{c|}{ Variables }} & $(1)$ & $(2)$ & $(3)$ & $(4)$ & \multicolumn{1}{c|}{$(5)$} \\
\cline { 2 - 6 } & $\mathrm{N}$ & Mean & \multicolumn{1}{c|}{ SD } & \multicolumn{1}{c|}{ Min } & \multicolumn{1}{c|}{ Max } \\
\hline Consumption & 612 & 18998.38 & 9302.303 & 4177.261 & 41578.88 \\
\hline Income & 612 & 29103.02 & 16311.59 & 4803.995 & 82707.57 \\
\hline working women & 612 & 6560.497 & 11732.26 & 71 & 70869 \\
\hline Young working women & 612 & 2314.614 & 4102.407 & 28 & 24834 \\
\hline Middle working women & 612 & 3171.031 & 5450.889 & 33 & 31989 \\
\hline Old working women & 612 & 1074.866 & 2301.465 & 3 & 16082 \\
\hline Men unemployment rate & 612 & 7.6 & 4.169989 & 1.3 & 25.6 \\
\hline Fertility rate & 612 & 1.679329 & 0.377544 & 1.076 & 3.11 \\
\hline Consumer price index & 612 & 2.754538 & 4.19018 & -4.478103 & 54.91537 \\
\hline Purchasing power parity & 612 & 44.70203 & 147.226 & 0.28 & 893.5 \\
\hline
\end{tabular}

Note: Consumption and income are stated in real, per capita terms. Data belongs to 36 OECD countries for the year 2000-2016.

Source: OECD statistics. https://stats.oecd.org/

\subsection{Diagnostic tests}

The empirical estimation includes different diagnostic tests for a more accurate estimation results. After data mining, several compulsory diagnostics were done to choose the appropriate estimation technique. Among them more important tests are on hand in this section. Before starting the mathematical calculation, a brief graphical explanation is presented below.

Figure 1 shows the change in the number of working women in OECD countries from the year 2000 to $2016^{22}$. The graph illustrates an obvious increase in number of working women throughout all the years. There is a diminutive drop off in the year 2007-08 but then it starts increasing gradually.

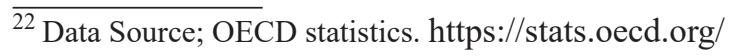


Figure 1: Total number of working women

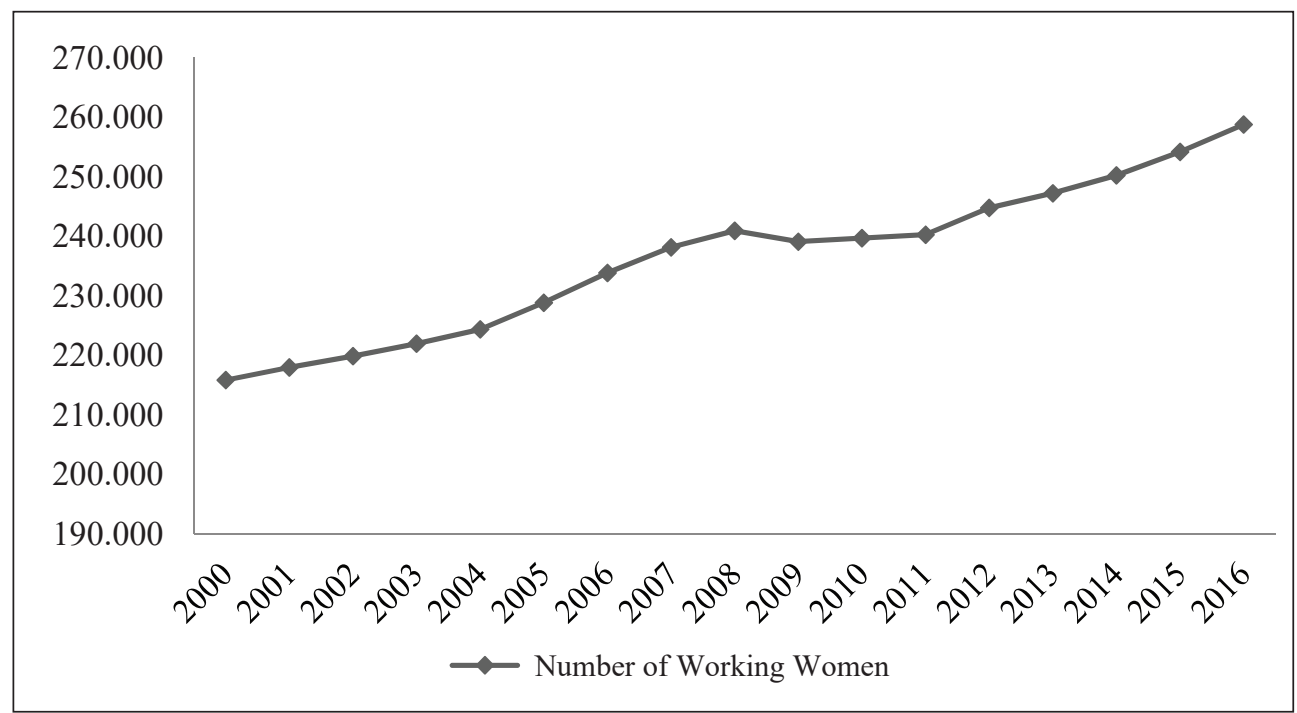

Figure 1 representing the trends in total number of working women (in thousands) in all OECD countries for the year 2000-2016.

Figure 2 represents the trends in per capita household consumption in 36 OECD countries from the year 2000 to 2016 .

Figure 2: Aggregate household per capita consumption

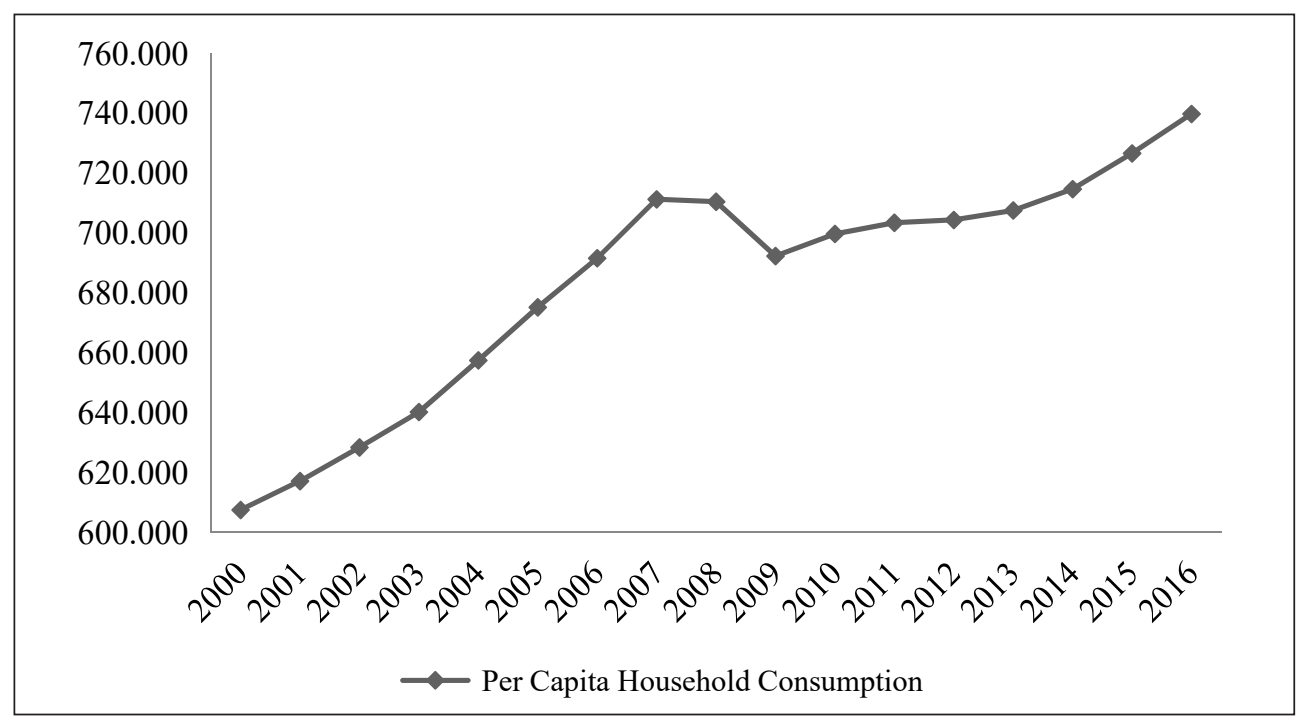


Wen Jun et al. •Working women and per capita household consumption expenditures...

It can be seen clearly that per capita household consumption increase from the year 2000 to 2007-2008, and then after a small decrease it start increasing from the year 2009 to 2016. Overall, the series also shows an increasing trend throughout the time.

Figure 2 representing the trends in aggregate household per capita consumption (in millions) in all OECD countries for the year 2000-2016.

In OECD countries, both the number of working women and per capita household consumption expenditures (shown in the figure 1 and 2) explain the similar increasing trend in the given time period 2000-2016. Figure 3 represents the trends in per capita household consumption expenditures and the number of working women in 36 OECD countries within the period 2000-2016 $6^{23}$.

Figure 3: Household per capita consumption expenditures and number of working women

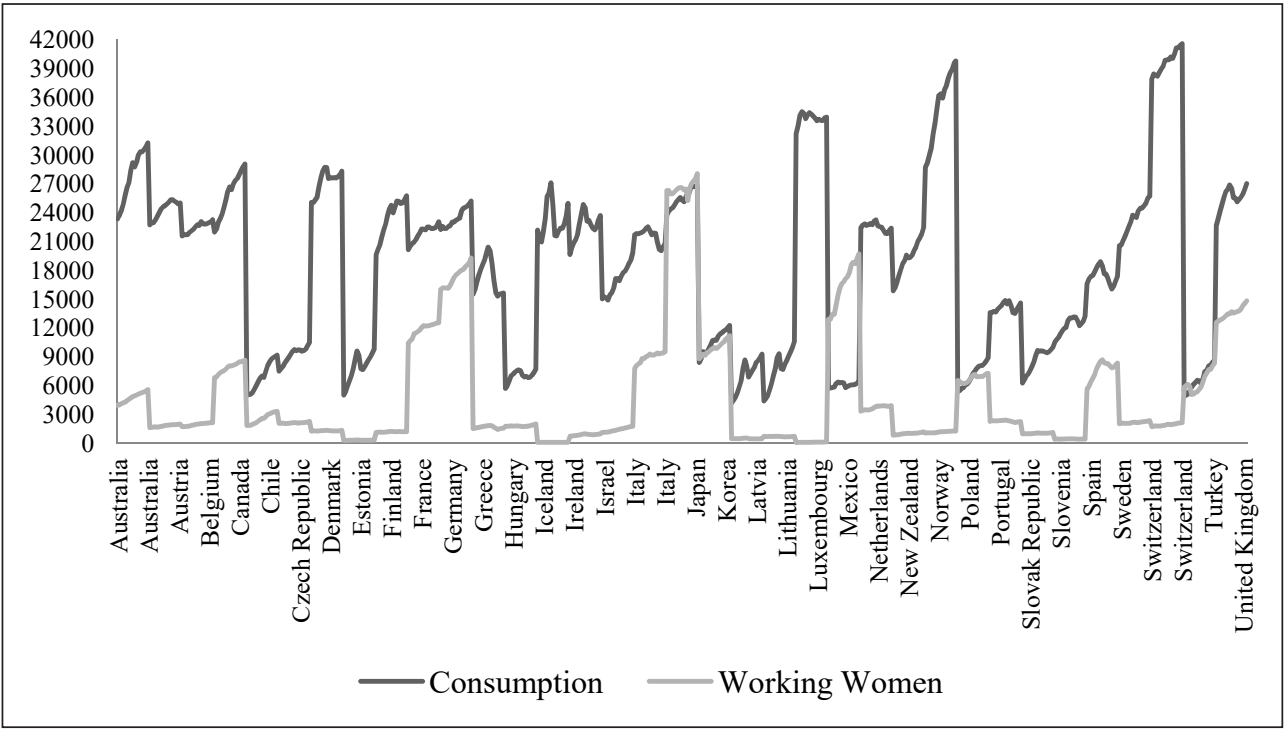

Figure 3 representing the trends in household per capita consumption expenditures (in millions) and number of working women (in thousands) in 35 OECD countries for the year 2000-2016.

It presents an increasing trend in both series across the panel of the individual country. Apparently, it can be observed that per capita consumption is moving along with the number of working women trend within the individual country for the respective 17 years. Since consumption expenditures are the most important and

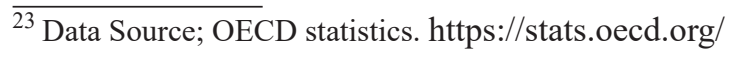


effective component of economic growth and as working women buying behavior is the determining factor of consumption expenditures, it is important to investigate how this factor can influence the level of per capita consumption.

\subsubsection{Cross-sectional dependence tests}

Table 2 shows the outcomes of the CD test and bias-adjusted LM test. Consequently, the null hypothesis of no cross-sectional dependence is rejected ${ }^{24}$, which points out that we ought to employ methods that are robust to cross-sectional dependence to evade inconsistent and biased outcomes.

Table 2: Cross-sectional dependence test results

\begin{tabular}{|l|c|}
\cline { 2 - 2 } \multicolumn{1}{c|}{} & Value \\
\hline CD Test & $2.57^{*}$ \\
\hline Bias Adjusted LM Test & 0.4418 \\
\hline
\end{tabular}

Note: $*, * *, * *$ indicate that statistics are significant at the $10 \%, 5 \%$, and $1 \%$ level of significance, respectively. The null hypothesis is no cross-sectional dependence.

\subsubsection{Unit Root and Cointegration Tests}

Table 3 illustrates the results of the CIPS unit root test. As the null hypothesis of a unit root possibly cannot be rejected, we bring to a close that all the variables are nonstationary in levels. Alternatively all variables are of level stationary with order I (1).

Table 3: CIPS Unit Root Test Results

\begin{tabular}{|l|c|c|}
\cline { 2 - 3 } \multicolumn{1}{c|}{} & \multicolumn{2}{c|}{ CIPS } \\
\cline { 2 - 3 } \multicolumn{1}{c|}{} & Intercept & Intercept Trend \\
\hline Consumption & -1.926 & -2.479 \\
\hline Income & -1.843 & -2.433 \\
\hline Working Women & -1.462 & -1.678 \\
\hline Fertility Rate & -1.625 & -2.469 \\
\hline CPI & -2.905 & -2.962 \\
PPP & -1.489 & -1.628 \\
\hline
\end{tabular}

Note: $*, * *, * * *$ indicate that statistics are significant at the $10 \%, 5 \%$, and $1 \%$ level of significance, respectively. For the CIPS test the null hypothesis is nonstationary.

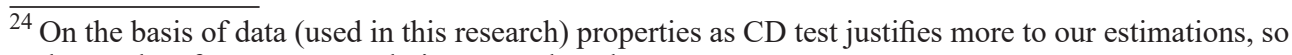
the results of $\mathrm{CD}$ test are only interpreted are here.
} 
As the all the variables are I (1), consequently we need to investigate whether the variables are cointegrated. It will enable us to use non-stationary series in levels exclusive of creating a spurious association if a linear arrangement of them is integrated in the midst of order zero (Atasoy 2017). Consequently, we make use of the second-generation Durbin-Hausman test developed by Westerlund (2008), which obtains cross-sectional dependence into account. The test creates two test statistics. The panel test (DHp) presumes that the autoregressive constraint is similar for all the sections. In results, rejection of the null hypothesis involves cointegration for all the cross-sections. The group test $(\mathrm{DHg})$ allows the autoregressive parameter to be different across cross-sections. In a similar way to the $\mathrm{DHg}$, if the null hypothesis is rejected, one brings to a close that cointegration exists.

Table 4: Durbin-Hausman cointegration test results

\begin{tabular}{|c|c|}
\cline { 2 - 2 } \multicolumn{1}{c|}{} & Value \\
\hline $\mathrm{DHg}$ & $-1.74 * * *$ \\
\hline $\mathrm{DHp}$ & $-4.25 * *$ \\
\hline
\end{tabular}

Note: $* * *, * * *$ indicate that statistics are significant at the $10 \%, 5 \%$, and $1 \%$ level of significance, respectively. The null hypothesis is no cointegration.

The results of the Durbin-Hausman test are shown in Table 4. Given that both the DHg and the DHp test refuse the null hypothesis of no cointegration, we finish off with hat the variables are cointegrated. In other words, the outcomes suggest that consumption has a long-term relation with income and number of working women.

\subsubsection{Causality check}

In addition to our conclusion from above test, we used the Granger causality test set up by Dumitrescu and Hurlin $(2012)^{25}$, which is robust to cross-sectional dependence and constraint heterogeneity. The test entails running Granger noncausality tests for all cross-sections individually.

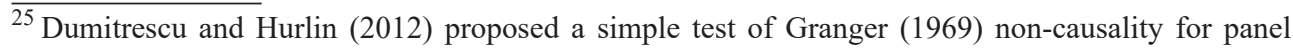
data estimations. The test statistic is based on the individual Wald statistics of non-causality across all the cross-sections. In Monte Carlo experiments, the test statistics have very good small sample properties, and also can be used in the presence of cross-sectional dependence.
} 
Wen Jun et al. • Working women and per capita household consumption expenditures... Zb. rad. Ekon. fak. Rij. $\cdot 2020 \cdot$ vol. $38 \cdot$ no. $1 \cdot 35-69$

Table 9: Dumitrescu-Hurlin panel causality test results

\begin{tabular}{|c|c|c|c|}
\hline Direction of Causality & Z_bar & Z_bar_tilde & Result \\
\hline $\begin{array}{l}\text { Income } \rightarrow \text { Consumption } \\
\text { Consumption } \rightarrow \text { Income }\end{array}$ & $\begin{array}{r}9.2079 * * * \\
7.3845 * * *\end{array}$ & $\begin{array}{l}6.1822 * * * \\
4.8460 * * *\end{array}$ & $\begin{array}{l}\text { Bidirectional } \\
\text { Causality }\end{array}$ \\
\hline $\begin{array}{l}\text { Working Women } \rightarrow \text { Consumption } \\
\text { Consumption } \rightarrow \text { Working Women }\end{array}$ & $\begin{array}{l}5.4083 * * * \\
9.6230 * * *\end{array}$ & $\begin{array}{l}3.3979 * * * \\
6.4864 * * *\end{array}$ & $\begin{array}{l}\text { Bidirectional } \\
\text { Causality }\end{array}$ \\
\hline $\begin{array}{l}\text { Men Unemployment rate } \rightarrow \text { Consumption } \\
\text { Consumption } \rightarrow \text { Men Unemployment rate }\end{array}$ & $\begin{array}{l}5.3195 * * * \\
5.1379 * * *\end{array}$ & $\begin{array}{l}3.3328 * * * \\
3.1997 * * *\end{array}$ & $\begin{array}{l}\text { Bidirectional } \\
\text { Causality }\end{array}$ \\
\hline $\begin{array}{l}\text { Fertility rate } \rightarrow \text { Consumption } \\
\text { Consumption } \rightarrow \text { Fertility rate }\end{array}$ & $\begin{array}{l}12.9122 * * * \\
24.6502 * * *\end{array}$ & $\begin{array}{l}8.8967 * * * \\
17.4982 * * *\end{array}$ & $\begin{array}{l}\text { Bidirectional } \\
\text { Causality }\end{array}$ \\
\hline $\begin{array}{l}\text { CPI } \rightarrow \text { Consumption } \\
\text { Consumption } \rightarrow \text { CPI }\end{array}$ & $\begin{array}{r}17.3294 * * * \\
4.6614 * * *\end{array}$ & $\begin{array}{r}12.1336 * * * \\
2.8506 * * *\end{array}$ & $\begin{array}{l}\text { Bidirectional } \\
\text { Causality }\end{array}$ \\
\hline $\begin{array}{l}\text { Working Women } \rightarrow \text { Income } \\
\text { Income } \rightarrow \text { Working Women }\end{array}$ & $\begin{array}{l}16.4488 * * * \\
29.3516 * * *\end{array}$ & $\begin{array}{l}11.4882 * * * \\
20.9433 * * *\end{array}$ & $\begin{array}{l}\text { Bidirectional } \\
\text { Causality }\end{array}$ \\
\hline $\begin{array}{l}\text { Men Unemployment rate } \rightarrow \text { Income } \\
\text { Income } \rightarrow \text { Men Unemployment rate }\end{array}$ & $\begin{array}{l}7.8613 * * * \\
7.8137 * * *\end{array}$ & $\begin{array}{l}5.1954 * * * \\
5.1605 * * *\end{array}$ & $\begin{array}{l}\text { Bidirectional } \\
\text { Causality }\end{array}$ \\
\hline $\begin{array}{l}\text { Fertility rate } \rightarrow \text { Income } \\
\text { Income } \rightarrow \text { Fertility rate }\end{array}$ & $\begin{array}{l}13.2222 * * * \\
15.4689 * * *\end{array}$ & $\begin{array}{r}9.1238 * * * \\
10.7702 * * *\end{array}$ & $\begin{array}{l}\text { Bidirectional } \\
\text { Causality }\end{array}$ \\
\hline $\begin{array}{l}\mathrm{CPI} \rightarrow \text { Income } \\
\text { Income } \rightarrow \text { CPI }\end{array}$ & $\begin{array}{r}16.1136 * * * \\
2.3986 * *\end{array}$ & $\begin{array}{r}11.2427 * * * \\
1.1924\end{array}$ & $\begin{array}{l}\text { Unidirectional } \\
\text { Causality from } \\
\text { CPI to Income }\end{array}$ \\
\hline $\begin{array}{l}\text { Men Unemployment rate } \rightarrow \text { Working Women } \\
\text { Working Women } \rightarrow \text { Men Unemployment rate }\end{array}$ & $\begin{array}{l}7.3845 * * * \\
9.2079 * * *\end{array}$ & $\begin{array}{r}4.8460 * * \\
6.1822 * * *\end{array}$ & $\begin{array}{l}\text { Bidirectional } \\
\text { Causality }\end{array}$ \\
\hline $\begin{array}{l}\text { Fertility rate } \rightarrow \text { Working Women } \\
\text { Working Women } \rightarrow \text { Fertility rate }\end{array}$ & $\begin{array}{l}7.3845 * * * \\
9.2079 * * *\end{array}$ & $\begin{array}{r}4.8460 * * \\
6.1822 * * *\end{array}$ & $\begin{array}{l}\text { Bidirectional } \\
\text { Causality }\end{array}$ \\
\hline $\begin{array}{l}\mathrm{CPI} \rightarrow \text { Working Women } \\
\text { Working Women } \rightarrow \text { CPI }\end{array}$ & $\begin{array}{l}7.3845 * * * \\
9.2079 * * *\end{array}$ & $\begin{array}{r}4.8460 * * \\
6.1822 * * *\end{array}$ & $\begin{array}{l}\text { Bidirectional } \\
\text { Causality }\end{array}$ \\
\hline $\begin{array}{l}\text { Fertility rate } \rightarrow \text { Men Unemployment rate } \\
\text { Men Unemployment rate } \rightarrow \text { Fertility rate }\end{array}$ & $\begin{array}{l}15.7111 * * * \\
16.7914 * * *\end{array}$ & $\begin{array}{l}10.9477 * * * \\
11.7393 * * *\end{array}$ & $\begin{array}{l}\text { Bidirectional } \\
\text { Causality }\end{array}$ \\
\hline $\begin{array}{l}\text { CPI } \rightarrow \text { Men Unemployment rate } \\
\text { Men Unemployment rate } \rightarrow \text { CPI }\end{array}$ & $\begin{array}{r}13.9992 * * * \\
6.5468 * * *\end{array}$ & $\begin{array}{l}9.6932 * * * \\
4.2321 * * *\end{array}$ & $\begin{array}{l}\text { Bidirectional } \\
\text { Causality }\end{array}$ \\
\hline $\begin{array}{l}\mathrm{PPP} \rightarrow \text { Men Unemployment rate } \\
\text { Men Unemployment rate } \rightarrow \text { PPP }\end{array}$ & $\begin{array}{l}7.3845 * * * \\
9.2079 * * *\end{array}$ & $\begin{array}{r}4.8460 * * \\
6.1822 * * *\end{array}$ & $\begin{array}{l}\text { Bidirectional } \\
\text { Causality }\end{array}$ \\
\hline $\begin{array}{l}\mathrm{CPI} \rightarrow \text { Fertility rate } \\
\text { Fertility rate } \rightarrow \text { CPI }\end{array}$ & $\begin{array}{r}1.0435 \\
3.0005 * *\end{array}$ & $\begin{array}{l}0.1994 \\
1.6334\end{array}$ & $\begin{array}{l}\text { Unidirectional } \\
\text { Causality from } \\
\text { CPI to Income }\end{array}$ \\
\hline
\end{tabular}

Note: $* * * * *, *$ denote the statistical significance at $99 \%$ level, $95 \%$ level, and $90 \%$ level, respectively. Lag orders have been selected according to the Akaike Information Criteria.

In view of that, table 9 suggests the existence of bidirectional causality between the pairs of consumption-income and consumption-working women. The results also show bidirectional causalities between all other variables except income-CPI and 
Wen Jun et al. •Working women and per capita household consumption expenditures...

fertility rate-CPI. The results suggest unidirectional causalities from income to CPI and from CPI to fertility rate.

\subsubsection{Other diagnosis}

Furthermore, heteroscedasticity has been also detected in our sample. Whereas, there is significant multicolinearity has been found in correlation matrix. In the presence of all these issues of cross-sectional dependence and heteroscedasticity, there is a need to estimate regressions with robust standard errors. Previous literature shows that consumption can be endogenous in several models (Campbell and Cocco 2007). To deal with this problem the models are then estimated using instrumental variable techniques; two-stage least-squares (2SLS) and generalized method of moments (GMM) with Driscoll and Kraay (1998) and cluster standard errors. Consumption and income are estimated through some instrument variables that affect these variables as well independent variable simultaneously. Instrumental variables include previous per capita consumption expenditures, previous per capita income, male unemployment rate, inflation, and previous per capita GDP. The use of a fixed or random effect model is then decided with Hausman test after fitting the auxiliary regression proposed by Wooldridge (2002) with cluster (IID) and Driscoll and Kraay standard errors ${ }^{26}$. This method is robust to the general form of cross-sectional dependence and heteroscedasticity. The insignificant test statistic for each model shows the presence of fixed effects. On the basis of these entire tests, hence it is decided that fixed effect models with two-stage least-squares (2SLS) and generalized method of moments (GMM) methodologies with Driscoll and Kraay (1998) and cluster standard errors are estimated.

\subsubsection{GMM and 2SLS estimations}

The results of the 2SLS and GMM estimations for the whole panel are depicted in Table 5 and Table 6 . The first column in both tables exhibits the results of the baseline specification, whereas the second, third and fourth columns present the results of the different age group specifications. As expected, income is the largest component of household aggregate final consumption, with a coefficient value of around $0.53-0.60$ in three specifications (Table 5). This implies that a 1 percent increase in the net real per capita national disposable income (income) causes a $0.53-0.60$ percent increase in household real per capita final consumption expenditure (consumption). The number of working women has an elasticity of around 0.16 in all specifications. This outcome implies that the number of working women and consumption are positively correlated and that a 1 percent increase in

\footnotetext{
${ }^{26}$ Driscoll and Kraay's methodology estimates the errors in this way that the covariance matrix estimator is consistent and independent of the cross-sectional dimension $\mathrm{N}$.
} 
the number of working women causes a 0.16 percent increase in consumption. Thus number of working women has a significant effect on consumption expendituresi.e. the higher the number of working women, the greater increase per capita household consumption expenditures.

Table 5: GMM Instrumental Variable Regression Estimation Results

\begin{tabular}{|c|c|c|c|c|}
\hline & Model 1 & Model 2 & Model 3 & Model 4 \\
\hline Income & $\begin{array}{r}0.5862 * * * \\
(0.0248) \\
\end{array}$ & $\begin{array}{r}0.6084 * * * \\
(0.0287) \\
\end{array}$ & $\begin{array}{r}0.5697 * * * \\
(0.0237) \\
\end{array}$ & $\begin{array}{r}0.5376^{* * * *} \\
(0.0127) \\
\end{array}$ \\
\hline Fertility Rate & $\begin{array}{r}0.0332 * * * \\
(0.0071) \\
\end{array}$ & $\begin{array}{r}0.0922 \\
(0.0075) \\
\end{array}$ & $\begin{array}{r}0.0106^{* * *} \\
(0.0119) \\
\end{array}$ & $\begin{array}{r}-0.0504 * * * \\
(0.0149) \\
\end{array}$ \\
\hline CPI & $\begin{array}{r}-0.0027 * * * \\
(0.0005) \\
\end{array}$ & $\begin{array}{r}-0.0019 * * * \\
(0.0002) \\
\end{array}$ & $\begin{array}{r}-0.0051^{* * * *} \\
(0.0011) \\
\end{array}$ & $\begin{array}{r}0.0018 * * * \\
(0.0004) \\
\end{array}$ \\
\hline PPP & $\begin{array}{r}-0.0006^{* * * *} \\
(0.0000) \\
\end{array}$ & $\begin{array}{r}-0.0006^{* * * *} \\
(0.0000) \\
\end{array}$ & $\begin{array}{r}-0.0006^{* * * *} \\
(0.0000) \\
\end{array}$ & $\begin{array}{r}-0.0006^{* * *} * \\
(0.0000) \\
\end{array}$ \\
\hline Working Women & $\begin{array}{r}0 . .1632 * * * \\
(0.0784) \\
\end{array}$ & & & \\
\hline Young Working Women & & $\begin{array}{r}0.1440 * * * \\
(0.0703)\end{array}$ & & \\
\hline Middle Working Women & & & $\begin{array}{r}0.2266^{* * *} \\
(0.0944) \\
\end{array}$ & \\
\hline Old Working Women & & & & $\begin{array}{r}0.0726^{* * *} \\
(0.0582) \\
\end{array}$ \\
\hline Observations & 611 & 611 & 611 & 611 \\
\hline Centered/ Uncenterd $\mathrm{R}^{2}$ & 0.5699 & 0.6080 & 0.4270 & 0.6950 \\
\hline Residual SS & 12.6169 & 11.5000 & 16.8086 & 8.9468 \\
\hline
\end{tabular}

Note: Here consumption is the dependent variable which is the log difference of real annual household per capita consumption, Income variable is the log differences of real, per capita annual income, fertility rate variables is the differences of annual fertility rate, CPI is the difference of annual CPI, PPP is the difference of annual PPP, Young working women represents the working women with the ages between 15 to 34 years old, Middle working women represents the working women with the ages between 35 to 54 years old, Old working women represents the working women with the ages between 54+ years old. Standard errors are given in the parentheses below the corresponding estimates. Centered/ Uncentered R-squares are given at the end.

$*$ Coefficient significant at the $10 \%$ level.; **Coefficient significant at the $5 \%$ level.; $* * *$ Coefficient significant at the $1 \%$ level.

However, the evidence for the whole panel also suggests counter-intuitive results. In this respect, Young, middle and old working women all have a positive significant relationship with consumption with the coefficient of $0.14,0.22$ and 0.07 respectively. This outcome implies that the number of young working women and consumption are positively correlated and that a 1 percent increase in the number of young working women causes a 0.14 percent increase in consumption. While for 
Wen Jun et al. •Working women and per capita household consumption expenditures...

middle and old age women a 1 percent increase in the number of young working women causes a 0.22 and 0.07 percent increase in consumption respectively. Thus the results show that age of working women does matter on their spending decision and eventually to overall consumption expenditures.

The results of 2SLS regression are presented in table 6 which are not much different the above presented GMM regression. As like the above one, the results of 2SLS regression (Table 6) estimation also show income coefficient value of around 0.53 0.60 in three specifications. This implies that a 1 percent increase in the net real per capita national disposable income (income) causes a $0.53-0.60$ percent increase in household real per capita final consumption expenditures (consumption).

Table 6: 2SLS Instrumental Variable Regression Estimation Results

\begin{tabular}{|c|c|c|c|c|}
\hline & Model 1 & Model 2 & Model 3 & Model 4 \\
\hline Income & $\begin{array}{r}0.5766 * * * \\
(0.0259)\end{array}$ & $\begin{array}{r}0.6025 * * * \\
(0.0291)\end{array}$ & $\begin{array}{r}0.5590 * * * \\
(0.0252)\end{array}$ & $\begin{array}{r}0.5314 * * * \\
(0.0135)\end{array}$ \\
\hline Fertility Rate & $\begin{array}{r}0.0350 * * * \\
(0.0072)\end{array}$ & $\begin{array}{r}0.0939 \\
(0.0076)\end{array}$ & $\begin{array}{r}0.0149 * * * \\
(0.0124)\end{array}$ & $\begin{array}{r}-0.0470 * * * \\
(0.0151)\end{array}$ \\
\hline CPI & $\begin{array}{r}-0.0031 * * * \\
(0.0006)\end{array}$ & $\begin{array}{r}-0.0021 * * * \\
(0.0003)\end{array}$ & $\begin{array}{r}-0.0061 * * * \\
(0.0013)\end{array}$ & $\begin{array}{r}0.0018^{* * *} \\
(0.0004)\end{array}$ \\
\hline PPP & $\begin{array}{r}-0.0006^{* * *} \\
(0.0000) \\
\end{array}$ & $\begin{array}{r}-0.0006^{* * *} \\
(0.0000) \\
\end{array}$ & $\begin{array}{r}-0.0006^{* * *} \\
(0.0000) \\
\end{array}$ & $\begin{array}{r}-0.0006^{* * *} \\
(0.0000) \\
\end{array}$ \\
\hline Working Women & $\begin{array}{r}0 . .1403^{* * *} \\
(0.0804) \\
\end{array}$ & & & \\
\hline Young Working Women & & $\begin{array}{r}0.1240 * * * \\
(0.0721)\end{array}$ & & \\
\hline Middle Working Women & & & $\begin{array}{r}0.2093 * * * \\
(0.0954)\end{array}$ & \\
\hline Old Working Women & & & & $\begin{array}{r}0.0449 * * * \\
(0.0619) \\
\end{array}$ \\
\hline Observations & 611 & 611 & 611 & 611 \\
\hline Centered/ Uncenterd $\mathrm{R}^{2}$ & 0.6191 & 0.6494 & 0.4704 & 0.7503 \\
\hline Residual SS & 11.1737 & 10.2860 & 15.5364 & 7.3236 \\
\hline
\end{tabular}

Note: Here consumption is the dependent variable which is the log difference of real annual household per capita consumption, Income variable is the log differences of real per capita annual income, fertility rate variables is the differences of annual fertility rate, CPI is the difference of annual CPI, PPP is the difference of annual PPP, Young working women represents the working women with the ages between 15 to 34 years old, Middle working women represents the working women with the ages between 35 to 54 years old, Old working women represents the working women with the ages between 54+ years old. Standard errors are given in the parentheses below the corresponding estimates. Centered/ Uncentered R-squares are given at the end.

* Coefficient significant at the $10 \%$ level.; ** Coefficient significant at the $5 \%$ level.; *** Coefficient significant at the $1 \%$ level. 
Income is the basic determinant of consumption expenditures. A slight change in income affects one's consumption/saving decision. While the other various factors also can contribute with income in interactive way and cause changes in consumption. The number of working women has an elasticity of around 0.14 , which is almost similar to the results of table 5, impending with the same theoretically consistent results. Likewise, the other results of 2SLS estimations are nearly the same with GMM estimation. The validity and consistency of these results are later checked for robustness in section 4.2.6.

\subsubsection{Robustness check}

The above results are then verified through robustness check. If the signs and magnitudes of the estimated coefficients in robustness check are also credible, this can be taken as the confirmation of coefficients consistency in above estimated regression ( $\mathrm{Lu}$ and White 2014).Hence the regression results coefficient can be reliably interpreted as accurate causal effects of the related independent variables, with all that this may bring about for policy making analysis and economic insight. Table 7 and 8 present the robust result of above GMM and 2SLS estimations. The results in Table 7 are almost similar as in table 5.

Robustness check make sure that how certain core estimated regression coefficients perform when the regression designs are modified in some way, usually by adding or removing variables. These robust command results show the validity of the coefficients in the above estimations. There is no difference in the signs of coefficient while showing a minor difference in their magnitudes. Similarly, the results of robust 2SLS regression in table 8 are similar as above in table 6 . 
Wen Jun et al. •Working women and per capita household consumption expenditures...

Table 7: Robust GMM Instrumental Variable Regression Estimation Results

\begin{tabular}{|c|c|c|c|c|}
\hline & Model 1 & Model 2 & Model 3 & Model 4 \\
\hline Income & $\begin{array}{r}0.54621 * \\
(0.0277)\end{array}$ & $\begin{array}{r}0.6092 * * * \\
(0.0137)\end{array}$ & $\begin{array}{r}0.5886 * * * \\
(0.0237)\end{array}$ & $\begin{array}{r}0.5501 * * * \\
(0.0217)\end{array}$ \\
\hline Fertility Rate & $\begin{array}{r}0.0332 * * * \\
(0.0101)\end{array}$ & $\begin{array}{r}0.0873 \\
(0.0066) \\
\end{array}$ & $\begin{array}{r}0.0210^{* * * *} \\
(0.0315)\end{array}$ & $\begin{array}{r}-0.0503 * * * \\
(0.02309) \\
\end{array}$ \\
\hline CPI & $\begin{array}{r}-0.0030 * * * \\
(0.0003)\end{array}$ & $\begin{array}{r}-0.0028 * * * \\
(0.0002)\end{array}$ & $\begin{array}{r}-0.0055^{* * * *}(0.0021) \\
(0.021)\end{array}$ & $\begin{array}{r}0.0014 * * * \\
(0.0000)\end{array}$ \\
\hline PPP & $\begin{array}{r}-0.0003 * * * \\
(0.0000)\end{array}$ & $\begin{array}{r}-0.0007 * * * \\
(0.0000)\end{array}$ & $\begin{array}{r}-0.0006^{* * * *} \\
(0.0000)\end{array}$ & $\begin{array}{r}-0.0006^{* * * *} \\
(0.0000)\end{array}$ \\
\hline Working Women & $\begin{array}{r}0 . .1643 * * * \\
(0.0644) \\
\end{array}$ & & & \\
\hline Young Working Women & & $\begin{array}{r}0.2014 * * * \\
(0.621)\end{array}$ & & \\
\hline Middle Working Women & & & $\begin{array}{r}0.2732 * * * \\
(0.08401)\end{array}$ & \\
\hline Old Working Women & & & & $\begin{array}{r}0.0719 * * * \\
(0.0501)\end{array}$ \\
\hline Observations & 611 & 611 & 611 & 611 \\
\hline Centered/ Uncenterd $\mathrm{R}^{2}$ & 0.6372 & 0.6550 & 0.5738 & 0.7029 \\
\hline Residual SS & 13.8194 & 11.0083 & 17.8843 & 10.5702 \\
\hline
\end{tabular}

Note: Here consumption is the dependent variable which is the log difference of real annual household per capita consumption, Income variable is the log differences of real, per capita annual income, fertility rate variables is the differences of annual fertility rate , CPI is the difference of annual CPI, PPP is the difference of annual PPP, Young working women represents the working women with the ages between 15 to 34 years old, Middle working women represents the working women with the ages between 35 to 54 years old, Old working women represents the working women with the ages between 54+ years old. Standard errors are given in the parentheses below the corresponding estimates. Centered/ Uncentered R-squares are given at the end.

** Coefficient significant at the $10 \%$ level.; ** Coefficient significant at the $5 \%$ level.; *** Coefficient significant at the $1 \%$ level.

Thus the above results regression coefficients can be interpreted as true estimators. Furthermore, the above estimations were also estimated through ordinary least squares. While, the results of basic ordinary least regressions are not presented in the above section. The results of basic regression also show quite similar signs and magnitudes of estimated coefficient. Thus, those results also add in the validity of estimated coefficients in GMM and 2SLS regressions. 
Wen Jun et al. • Working women and per capita household consumption expenditures...

Table 8: Robust 2SLS Instrumental Variable Regression Estimation Results

\begin{tabular}{|c|c|c|c|c|}
\hline & Model 1 & Model 2 & Model 3 & Model 4 \\
\hline Income & $\begin{array}{r}0.4903 * * * \\
(0.0101) \\
\end{array}$ & $\begin{array}{r}0.6122 * * * \\
(0.0282) \\
\end{array}$ & $\begin{array}{r}0.5352 * * * \\
(0.0202) \\
\end{array}$ & $\begin{array}{r}0.5314 * * * \\
(0.0029) \\
\end{array}$ \\
\hline Fertility Rate & $\begin{array}{r}0.0312 * * * \\
(0.0066) \\
\end{array}$ & $\begin{array}{r}0.0882 \\
(0.0068) \\
\end{array}$ & $\begin{array}{r}0.0156^{* * * *} \\
(0.0119) \\
\end{array}$ & $\begin{array}{r}-0.0392 * * * \\
(0.0122) \\
\end{array}$ \\
\hline CPI & $\begin{array}{r}-0.0030 * * * \\
(0.0006)\end{array}$ & $\begin{array}{r}-0.0028 * * * \\
(0.0008) \\
\end{array}$ & $\begin{array}{r}-0.0058^{* * *} \\
(0.0011) \\
\end{array}$ & $\begin{array}{r}0.0017 * * * \\
(0.0003)\end{array}$ \\
\hline PPP & $\begin{array}{r}-0.0006^{* * *} \\
(0.0000) \\
\end{array}$ & $\begin{array}{r}-0.0006^{* * *} \\
(0.0000) \\
\end{array}$ & $\begin{array}{r}-0.0006^{* * *} \\
(0.0000) \\
\end{array}$ & $\begin{array}{r}-0.0006^{* * *} \\
(0.0000) \\
\end{array}$ \\
\hline Working Women & $\begin{array}{r}0 . .1392 * * * \\
(0.0737) \\
\end{array}$ & & & \\
\hline Young Working Women & & $\begin{array}{r}0.1137 * * * \\
(0.0700) \\
\end{array}$ & & \\
\hline Middle Working Women & & & $\begin{array}{r}0.2334 * * * \\
(0.0873) \\
\end{array}$ & \\
\hline Old Working Women & & & & $\begin{array}{r}0.0437 * * * \\
(0.0583) \\
\end{array}$ \\
\hline Observations & 611 & 611 & 611 & 611 \\
\hline Centered/ Uncenterd $\mathrm{R}^{2}$ & 0.7249 & 0.7330 & 0.6258 & 0.8128 \\
\hline Residual SS & 13.2491 & 11.2979 & 17.3398 & 9.8942 \\
\hline
\end{tabular}

Note: Here consumption is the dependent variable which is the log difference of real annual household per capita consumption, Income variable is the log differences of real per capita annual income, fertility rate variables is the differences of annual fertility rate, CPI is the difference of annual CPI, PPP is the difference of annual PPP, Young working women represents the working women with the ages between 15 to 34 years old, Middle working women represents the working women with the ages between 35 to 54 years old, Old working women represents the working women with the ages between 54+ years old. Standard errors are given in the parentheses below the corresponding estimates. Centered/ Uncentered R-squares are given at the end.

* Coefficient significant at the $10 \%$ level.; ** Coefficient significant at the 5\% level.; *** Coefficient significant at the $1 \%$ level.

On the basis of above all empirical results, we further explain the implication and augmentation of the phenomenon discussed in this research in next sections.

\section{Results and discussions}

The results in above section demonstrate the approval of all of three null hypotheses. Firstly, the statistically significant coefficient estimates in all regressions indicates that the number of working women has a considerable effect on consumption expenditures. Secondly, the positive coefficient estimates explain that the numbers of working women increase per capita household spending and an increase in number of working women will increase per capita 
Wen Jun et al. •Working women and per capita household consumption expenditures...

household consumption expenditures. Thirdly, the results clearly show that age of working women does matter on their spending decision and eventually to overall consumption expenditures.

As explained in above sections, working women compulsive buying behavior makes them spend relatively more than men. Except from income effect, there are other reasons making working women particularly to spend larger proportions of their income. These empirical results are consistent with the theoretical framework formed by this study. High number of working women has significantly positive effect on consumption expenditures. Thus, the results can be generalized as the countries with high percentages of working women have a positive effect on their per capita household expenditures, leading a higher economic growth. These finding illustrate the importance of females in jobs, which brings a considerable difference gross domestic product through elevated consumption levels. Age is an important factor considering spending behavior of women. The coefficient obtained for different age groups illustrate better understanding of the impact of female spending on consumption expenditures. A high percentage of middle age women in jobs would boost up economy through high their high spending as compare to young and old age women. Thus, the countries with high proportion of middle age working women have edge on their better level of consumption expenditures. These results provide a very clear understanding for the policy makers of the working women spending behavior phenomenon and the observable fact related to the contribution in economic output.

As, mentioned earlier middle age working women spend more on family expenditures. Their spending may increase due to various reasons, such as increase in income, spending on children and husband, spending on housing etc. Thus, the results showing highest coefficient for middle age women are theoretically and economically significant. While, young age women following middle age women have relatively more compulsive buying behavior to old age women. Generally, women in old age have fewer things to spend on than in young age. Thus, all the results justify the above presented whole theoretical phenomenon of working women spending behavior and their effect on household per capita consumption.

Moreover, CPI and PPP have negative significant on household per capita consumption while fertility rate has significantly positive, relations in three of these specifications. These results are consistent with economic theory. As the level of inflation and purchasing power parities increases, it affects household per capita expenditures negatively. With the decrease in rate of CPI and PPP, people would be able to increase their consumption expenditures. Also, with increasing fertility rate, due to scarce resources, one would have negative effect on personal consumption expenditures. All the coefficients are showing consumption elasticities with respect to the individual variable. This means these coefficients are showing the percentage changes in consumption with respect to their individual variable. 


\section{Conclusion}

In the light of the phenomenon that working women have more compulsive buying propensities, which can lead to a significant increase in their consumption expenditures, the important research question is: How changes in the number of working women affect their consumption pattern within the household and do they have a discernible impact on household per capita consumption expenditure? This research explores the effects of changes in the number of working women on household per capita consumption. The results from two-stage least squares (2SLS) and generalized method of moments (GMM) techniques show that the increase in the number of working women has a significantly positive effect on the household final per capita consumption expenditure. The result also implies that age plays a significant role in working women consumption decision making. As compared to young and old age, middle-aged working women are more responsive to increase in household final per capita consumption expenditure. As well the number of young age working women affect consumption expenditures more than number of old age working women. Hence, middleaged working women add more in aggregate consumption than other age groups. In real term, this result is according to long-term women spending behavior. Though young working women relatively considered as more compulsive buyers, however, due to higher income and family expenditures in middle age, we can say middle age working women are more responsive to an increase in consumption expenditures.

This research supports the alternative hypotheses as it designates that habitual working woman spending behavior leads to add in household per capita consumption expenditures. There are limited numbers of such studies measuring the effect of working women on the economy through consumption channel. The research on macro level indicates broad understanding on women's spending behavior on economy. The findings on the changes in household per capita consumption through a change in the number of working women nexus have imperative policy allegations and ought to be of interest to policymakers, market partakers, and researchers. Particularly for the countries with low women participation in economic activities, this study is constructive for future policy making.

The study gives a better understanding of female psychological spending behavior. Not only has it explained the observable fact empirically but also explained the theoretical aspects of working women purchasing behavior. Further amplification of this research should be a major apprehension at this time. As in the case of many developing economies, women's liberation movement adds much deeper and wider based support. Thus, this research can be further extended to other regions. Moreover, the questions of women spending behavior on household consumption expenditure can be deeply examine using micro level data. Mastering the implications of these key social forces is therefore likely to be crucial for understanding future improvements in consumption patterns and growth. 
Wen Jun et al. - Working women and per capita household consumption expenditures...

\section{Acknowledgement}

All authors are jointly acknowledged for the research strategies of this paper. Special contribute to Prof. Wen Jun whose valuable knowledge made the research enhanced and accurate.

\section{References}

Addessi, W. (2018) "Population Age Structure and Consumption Expenditure Composition: Evidence from European Countries", Economics Letters, Vol. 168, pp. 18-20, https://doi.org/10.1016/j.econlet.2018.03.033.

Albanesi, S. (2017) “Changing Business Cycles: The role of Women's Employment”, Meeting Papers, Society for Economic Dynamics.

Anderson, S., Mukesh E. (2009) "What Determines Female Autonomy? Evidence from Bangladesh", Journal of Development Economics, Vol. 90, No. 2, pp. 179-191, https://doi.org/10.1016/j.jdeveco.2008.10.004.

ANN, C., Foster, S., Mammen. (1992) “Impact of Wife's Employment on Service Expenditures", Journal of Consumer Studies \& Home Economics, Vol. 16, No. 1, pp. 9-18, https://doi.org/0.1111/j.1470-6431.1992.tb00495.x.

Apps, Patricia F., Ray R. (1997) "Collective Labor Supply and Household Production", Journal of Political Economy, Vol. 105, No. 1, pp. 178-190, https://doi.org/10.1086/262070.

Asumadu-Sarkodie, S., Owusu, P. A., Zhang X. (2016) "The Casual Nexus Between Child Mortality Rate, Fertility Rate, GDP, Household Final Consumption Expenditure, and Food Production Index", Cogent Economics \& Finance, Vol. 4, No. 1, pp. 1-15, http://dx.doi.org/10.1080/23322039.2016.1191985.

Atasoy, B. S. (2017) "Testing the Environmental Kuznets Curve Hypothesis across the US: Evidence from Panel Mean Group Estimators", Renewable \& Sustainable Energy Reviews, Vol. 77, pp. 731-747, http://dx.doi.org/10.1016/j.rser.2017.04.050.

Bank, A. D. (2014) "Purchasing Power Prities and Real Expenditures: A Summary Report", ADB Reports.

Beblo, M., Beninger, D. (2012) "Do Husbands and Wives Pool Their Incomes? Experimental Evidence", Working Papers of Beta, Vol. 234, No. 6, pp. 120141, http://dx.doi.org/10.3848/iif.2014.337.392.

Bhupal, G., Sam, A. G. (2014) "Female Income and Expenditure on Children: Impact of the National Rural Employment Guarantee Scheme in India", Applied Econometrics \& International Development, Vol. 14, No. 2, pp. 175-192.

Bhupal, G., Sam, A. G. (2014) "Female Income and Expenditure on Children: Impact of the National Rural Employment Guarantee Scheme in India," Applied Econometrics \& International Development, Vol. 14, No. 2, pp. 175-192. 
Biyun, Y., Lingshuang, Z., Xingjian, Y. I. (2014) "Determinants of Household Consumption Expenditures for Services: An Empirical Study Based on Urban Household Survey Data", Finance \& Trade Economics, Vol. 6, pp. 122-136.

Bourguignon, F., Browning, M., Chiappori, P. A., Lechene, V. (1993) "Intra Household Allocation of Consumption", Annales Déconomie Et De Statistique, Vol. 29, pp. 137-156, http://dx.doi.org/10.1006/redy.2002.0191.

Browning, M., Pierre-André C., Valérie L. (2010) "Distributional Effects in Household Models: Separate Spheres and Income Pooling", Economic Journal, Vol. 120, No. 545, pp. 786-799, https://doi.org/10.1111/j.1468-0297.2009. 02311.x.

Browning, M., Pierre-Andre, C., Arthur L. (2013) "Estimating Consumption Economies of Scale, Adult Equivalence Scales, and Household Bargaining Power", Review of Economic Studies, Vol. 80, No. 4, pp. 1267-1303, https:// doi.org/10.1093/restud/rdt019.

Campbell, J. Y., Joao F. C. (2007) "How do House Prices Affect Consumption? Evidence from Micro Data", Journal of monetary Economics, Vol. 54, No. 3, pp. 591-621, https://doi.org/10.1016/j.jmoneco.2005.10.016.

Chen, Z., Woolley, F. (2001) "A Cournot-Nash Model of Family Decision Making”, Economic Journal, Vol. 111, No. 474, pp. 722-748, https://doi.org/10.1111/14680297.00657.

Chudik, A., Pesaran, M. H. (2013) "Large Panel Data Models with Cross-sectional Dependence: A Survey", Working Paper, CESifo Working Paper, No. 4371v, https://doi.org/10.2139/ssrn.2316333.

D'Aspremont, C., Ferreira, R. D. S. (2019). "Enlarging the Collective Model of Household Behavior: A Revealed Preference Analysis", Economic Theory, Vol. 68, No. 1, pp. 1-19, https://doi.org/10.1007/s00199-018-1110-3.

Datta, G., Meerman, J. (1980) "Household Income or Household Income per Capita in Welfare Comparisons", Review of Income and Wealth, Vol. 26, No. 4, pp. 401-418.

Desta, C. G., (2014) "Fertility and Household Consumption Expenditure in Ethiopia: A Study in the Amhara Region", Journal of Population and Social Studies, Vol. 22, pp. 202-218, https://doi.org/10.14456/jpss.2014.12.

Dittmar, H., \& Drury, J. (2000) "Self-image - Is It in the Bag? A Qualitative Comparison Between "Ordinary" and "Excessive" Consumers", Journal of Economic Psychology, Vol. 21, No. 2, pp. 109-142, https://doi.org/10.1016/ S0167-4870(99)00039-2.

Dittmar, H., Weber, E. U., Baron, J., Loomes, G. (2001) "Impulse Buying in Ordinary and Compulsive Consumers", Cambridge University Press.

Dreger, C., Reimers, H. (2012) "The Long Run Relationship Between Private Consumption and Wealth: Common and Idiosyncratic Effects", Portuguese Economic Journal, Vol. 11, pp. 21-34, https://doi.org/10.1007/s10258-011-0075-y. 
Wen Jun et al. - Working women and per capita household consumption expenditures...

Dumitrescu, E. I., Christophe H. (2012) "Testing for Granger Non-Causality in Heterogeneous Panels", Economic Modelling, Vol. 29, No. 4. pp. 1450-1460, https://doi.org/10.1016/j.econmod.2012.02.014.

Fisher, P. J. (2010) "Gender Differences in Personal Saving Behaviours", Journal of Financial Counselling \& Planning, Vol. 21. No. 1, pp. 14-24.

Han, N. W., Hung, M. W. (2006) "Estimated Inflation Rate, Consumption and Portfolio Decision”, Economics Letters, Vol. 92, No. 3, pp. 402-408, https:// doi.org/10.1016/j.econlet.2006.03.020.

Helga D., Jane B., Susanne F. (2004) "Gender Identity and Material Symbols: Objects and Decision Considerations in Impulse Purchases", Journal of Economic Psychology, Vol. 16, No. 3, pp. 491-511, https://doi.org/10.1016/ 0167-4870(95)00023-H.

Hernández-Salmerón, M., Romero-Ávila D. (2015) "Econometric Methods. In: Convergence in Output and Its Sources Among Industrialised Countries", Springer Briefs in Economics. Springer, Cham, pp. 15-24, https://doi.org/ 10.1007/978-3-319-13635-6_3.

Hirschman, E. C. (1992) "The Consciousness of Addiction: Toward a General Theory of Compulsive Consumption", Journal of Consumer Research, Vol. 19, No. 2, pp. 155-179, https://doi.org/10.1086/209294.

Hoddinott, J., and Lawrence H. (1995) "Does Female Income Share Influence Household Expenditure? Evidence from Cote d'Ivoire", Oxford Bulletin of Economics and Statistics, Vol. 57, No. 1, pp. 77-96, https://doi.org/10.1111/ j.1468-0084.1995.tb00028.x.

Hopkins, J., Carol L., Lawrence H. (1994) "Women's Income and Household Expenditure Patterns: Gender or Flow? Evidence from Niger", American Journal of Agricultural Economics, Vol. 76, No. 5, pp. 1219-1225, https://doi. org/10.2307/1243421.

Hossain, M. J., Al-Amin, A. K. M. A. (2018) "Non-farm Income and Consumption Expenditures in Rural Bangladesh: Empirical Evidence from Multilevel Regression Modeling", Journal of Quantitative Economics, Vol. 17, No. 2, pp. 1-20, https://doi.org/10.1007/s40953-018-0134-7.

Im, Kyung S., Hashem P., Yongcheol S. (2003) "Testing for Unit Roots in Heterogeneous Panels", Journal of econometrics, Vol. 115, No. 1, pp. 53-74, https://doi.org/10.1016/S0304-4076(03)00092-7.

Inoue, A., Kilian, L., Kiraz, F. B. (2009) "Do Actions Speak Louder Than Words? Household Expectations of Inflation Based on Micro Consumption Data", Journal of Money, Credit and Banking, Vol. 41, No. 7, pp. 1331-1363, https:// doi.org/10.1111/j.1538-4616.2009.00259.x.

John, C., Driscoll, Aart, C., Kraay. (1998) "Consistent Covariance Matrix Estimation With Spatially Dependent Panel Data", Review of Economics \& Statistics, Vol. 80, No. 4, pp. 549-560, https://doi.org/10.1162/003465398557825. 
Joireman, J., Jeremy K., David S. (2010) “Concern With Immediate Consequences Magnifies the Impact of Compulsive Buying Tendencies on College Students' Credit Card Debt", Journal of Consumer Affairs, Vol. 44, No. 1, pp. 155-178, https://doi.org/10.1111/j.1745-6606.2010.01161.x.

Joji, N. A., Raveendran, P. T. (2008) "Compulsive Buying Behavior in Indian Consumers and Its Impact on Credit Default- An Emerging Paradigm". Indian Institute of Management Kozhikode.

Juhl, T., Oleksandr L. (2014) "A Test for Slope Heterogeneity in Fixed Effects Models", Econometric Reviews, Vol. 33, No. 8, pp. 906-935, https://doi.org/10. 1080/07474938.2013.806708.

Keng, S. H., Chun-Hung L. (2005) "Wives' Value of Time and Food Consumed Away from Home in Taiwan", Asian Economic Journal, Vol. 19, No. 3, pp. 319-334, https://doi.org/10.1111/j.1467-8381.2005.00215.x.

Killewald, A. (2011) “Opting Out and Buying Out: Wives' Earnings and Housework Time", Journal of Marriage and Family, Vol. 73, No. 2, pp. 459-471, https:// doi.org/10.1111/j.1741-3737.2010.00818.x.

Koç, E. (2015) “Job Finding, Job Loss and Consumption Behaviour", Social Science Electronic Publishing, 2015-015, http://dx.doi.org/10.2139/ssrn.2574185.

Kornrich, S., Roberts, A. (2017) "Household Income, Women's Earnings, and Spending on Household Services, 1980-2010", Journal of Marriage and Family, Vol. 80, No. 1, pp. 150-165, https://doi.org/10.1111/jomf.12450.

Lancaster, G., Pushkar, M., Ranjan R. (2008) "Household Expenditure Patterns and Gender Bias: Evidence from Selected Indian States", Oxford Development Studies, Vol. 36, No. 2, pp. 133-157, http://dx.doi.org/10.1080/13600810802037803.

Lee, J. (2007) "Marriage, Sharing Rule, and Pocket Money: The Case of Korea", Economic Development and Cultural Change, Vol. 55, No. 3, pp. 557-582, https://doi.org/10.1086/511194.

Lee, S., Jinkook, L., Yunhee, C. (2011) "What is the Cost of Married Women's Paid Work?" RAND Working Paper, Series No. WR-830, http://dx.doi.org/10.2139/ ssrn.1749698.

Lee, S., Jinkook, L., Yunhee, C. (2014) "Is Dual Income Costly for Married Couples? An Analysis of Household Expenditures", Journal of Family and Economic Issues, Vol. 35, No. 2, pp. 161-177, https://doi.org/10.1007/s10834013-9364-1.

Lu, X., White, H. (2014) "Robustness Checks and Robustness Tests in Applied Economics", Journal of Econometrics, Vol. 178, No. 1, pp.194-206, https://doi. org/10.1016/j.jeconom.2013.08.016.

Manchanda, R. (2010) "A Comparative Study of Compulsive Buying Behaviour Between Working and Non-Working Women", Pragyaan Journal of Management, Vol. 27, No. 28, pp. 1-9. 
Wen Jun et al. - Working women and per capita household consumption expenditures...

Manchanda, R. (2015) "Materialism and Compulsive Buying: An Exploration of Indian Youth", International Journal of Business Quantitative Economics and Applied Management Research, Vol. 2, No. 4, pp. 28-40.

Mccarthy, N., Kilic, T. (2015) "The Nexus Between Gender, Collective Action for Public Goods and Agriculture: Evidence from Malawi."Agricultural Economics, Vol. 46, No. 3, pp. 375-402, https://doi.org/10.1111/agec.12170.

Pesaran, M. H. (2004) "General Diagnostic Tests for Cross Section Dependence in Panels." CESifo Working Paper Series No. 1229; IZA Discussion Paper No. 1240. Available at: https://ssrn.com/abstract $=572504$.

Pesaran, M. H. (2007) "A Simple Panel Unit Root Test in the Presence of CrossSection Dependence", Journal of applied econometrics, Vol. 22, No. 2, pp. 265-312, https://doi.org/10.1002/jae.951.

Pesaran, M. H., Takashi, Y. (2008) "Testing Slope Homogeneity in Large Panels." Journal of Econometrics, Vol. 142, No. 1, pp. 50-93, https://doi.org/10.1016/j. jeconom.2007.05.010.

Phipps, S. A., Peter, S. B. (1998) "What's Mine is Yours? The Influence of Male and Female Incomes on Patterns of Household Expenditure", Economica, Vol. 65, No. 260, pp. 599-613, https://doi.org/10.1111/1468-0335.00148.

Sarafidis, V., Donald, R. (2008) "On the Impact of Error Cross-Sectional Dependence in Short Dynamic Panel Estimation", The Econometrics Journal, Vol. 12, No. 1, pp. 62-81, https://doi.org/10.1111/j.1368-423X.2008.00260.x.

Schmeer, K. K. (2005) "Married Women's Resource Position and Household Food Expenditures in Cebu, Philippines", Journal of Marriage and Family, Vol. 67, No. 2, pp. 399-409, https://doi.org/10.1111/j.0022-2445.2005.00124.x.

Schultz, T. P. (1990) "Testing the Neoclassical Model of Family Labor Supply and Fertility", Journal of Human resources, Vol. 25, No. 4, pp. 599-634V, http:// www.jstor.org/stable/145669.

Shotick, J. A. (2015) "Trade-Off of Expenditures for Food Away from Home for the Wife's Housework Time by Employment Status", In Proceedings of the 1999 Academy of Marketing Science (AMS) Annual Conference, pp. 6-10. Springer, Cham, https://doi.org/10.1007/978-3-319-13078-1_2.

Slacalek, J. (2009) "What Drives Personal clConsumption? The Role of Housing and Financial Wealth",The BE Journal of Macroeconomics, Vol. 9, No. 1, https://doi.org/10.2202/1935-1690.1555.

Soberon-Ferrer, H., Rachel D. (1991) "Determinants of Household Expenditures for Services", Journal of Consumer Research, Vol. 17, No. 4, pp. 385-397, https://doi.org/10.1086/208565.

Svaleryd, H. (2009) "Women's Representation and Public Spending", European Journal of Political Economy, Vol. 25, No. 2, pp. 186-198, https://doi.org/ 10.1016/j.ejpoleco.2008.12.004. 
Watson, D., Maître, B., Cantillon, S. (2013) "Technical Paper on Implications of Income Pooling \& Household Decision Making for the Measurement of Poverty and Deprivation - An Analysis of the SILC 2010 Special Module for Ireland." Openaccess, http://hdl.handle.net/2262/73515.

Weese, G. D., Norton, M. J. T. (1991) "Impact of married women's employment on individual household member expenditures for clothing", Journal of Consumer Affairs, Vol. 25, No. 2, pp. 235-257, https://doi.org/10.1111/j.1745-6606.1991. tb00004.x.

Westerlund, J. (2008) "Panel Cointegration Tests of the Fisher Effect." Journal of Applied Econometrics, Vol. 23, No. 2, pp. 193-233, https://doi.org/10.1002/ jae.967.

Zamora, B. (2011) "Does Female Participation Affect the Sharing Rule?" Journal of Population Economics", Vol. 24, No. 1, pp. 47-83, https://doi.org/10.1007/ s00148-008-0208-5. 
Wen Jun et al. •Working women and per capita household consumption expenditures...

\title{
Zaposlene žene i izdaci potrošnje kućanstava po glavi stanovnika: neistražena/nedodirnuta stvarnost
}

\author{
Wen Jun ${ }^{1}$, Junaid Waheed ${ }^{2}$, Hadi Hussain ${ }^{3}$, Ihsan Jamil $^{4}$, Denisa Borbášová ${ }^{5}$, \\ Muhammad Khalid Anser 6
}

\begin{abstract}
Sažetak
Zaposlene žene sklonije su kompulzivnoj kupovini što može dovesti do značajnog povećanja izdataka za potrošnju kućanstava. U ovom radu istražuje se utjecaj promjene broja zaposlenih žena na potrošnju kućanstva po glavi stanovnika. Testira se hipoteza da promjena u broju zaposlenih žena ima značajan utjecaj na izdatke finalne potrošnje kućanstva per capita, zbog različitih sklonosti potrošnji, a provedena je empirijska analiza temeljena na skupu panel podataka 36 gospodarstava OECD-a u razdoblju 2000. - 2016. Rezultati pokazuju da promjena broja zaposlenih žena povećava rashode kućanstva per capita. Nadalje, rezultati impliciraju da životna dob zaposlenih žena ima vrlo značajnu ulogu u donošenju odluka o potrošnji što može dovesti do značajnih razlika u ukupnim izdacima potrošnje. Ovi rezultati ukazuju na važnost razumijevanja činjenice da promjena broja zaposlenih žena utječe $i$ na planiranje ukupne potrošnje i formuliranje politika gospodarskog rasta.
\end{abstract}

Ključne riječi: kupovno ponašanje zaposlenih žena, izdaci za potrošnju kućanstva po stanovniku/per capita, rast BDP-a, empirijska studija, zemlje OECD-a

JEL klasifikacija: D12, D91, J16

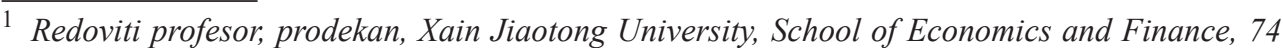
Yanta Road, Xian, 710000, Kina. Znanstveni interes: primijenjena ekonomija, korporativne financije, industrijska organizacija i inovacije poduzeća. Tel.: +86 029-82656840. E-mail: wjun1978@163.com.

2 Doktorand, Xain Jiaotong University, School of Economics and Finance, 74 Yanta Road, Xian, 710000, Kina. Znanstveni interes: primijenjena ekonomija, makroekonomija, ponašanje potrošača i inovacije. Tel: +86 18149056075.E-mail: junaidwaheed@stu.xjtu.edu.cn. (osoba za kontakt).

3 Doktorand, Xain Jiaotong University, School of Economics and Finance, 74 Yanta Road, Xian, 710000, Kina. Znanstveni interes: Primijenjena ekonomija, industrijska organizacija, korporativne financije, korporativno upravljanje i inovacije poduzeća. E-mail: hussainhadi@ stu.xjtu.edu.cn.

4 Doktorand-istraživač, Xain Jiaotong University, School of Economics and Finance, 74 Yanta Road, Xian, 710000, Kina. Znanstveni interes: makroekonomija, ekonomija poljoprivrede, inovacije i javna politika.E-mail: ihsanjamil@stu.xjtu.edu.cn.

5 Magistar ekonomskih znanosti, student, Xain Jiaotong University, School of Management, 28 Xianning Road, Xian, 710000, Kina. Znanstveni interes: upravljačka ekonomija, analiza ponašanja potrošača i studije potrošača.E-mail: borbasova.d@gmail.com.

${ }^{6}$ Doktorand-istraživač, School of Management, Xi'an University of Architecture and Technology, Beilin, 710000, Kina. Znanstveni interes: primijenjena ekonomija, industrijska organizacija, korporativne financije i korporativno upravljanje.E-mail: khalidsnnu@gmail.com. 